\title{
An Evaluative Study of Political Thinking of B.R.Ambedkar: A Critical Underpinning
}

\author{
Dr. Ishita Aditya \\ Associate Professor, Bejoy Narayan Mahavidyalaya, Under University of Burdwan, West Bengal, India
}

\begin{abstract}
This article, besides reflecting the theoretical issues that are implicated in the writings of Ambedkar, attempts to capture the position of Ambedkar on issues whose relevance is actually felt even in the present day. The complex issues which Ambedkar explained and defended, although not always to the satisfaction of many and sometimes not as rigorously as required, have continued to claim intellectual and political attention to this day in many societies and especially in India. Therefore, the present study is an attempt to make a comprehensive and objective analysis of the various strands of the political ideas of Ambedkar while keeping in minds the gaps and lapses in the existing literature on Ambedkar.
\end{abstract}

DOI: $10.7176 / \mathrm{HRL} / 48-01$

\section{Introduction}

Born in a socially backward caste, educated along the lines of the western system, rational in outlook and somewhat rebellious in mentality and temperament, Bhimrao Ramji Ambedkar (1891-1956), 'a symbol of revolt' (as called by Jawaharlal Nehru) came at the appropriate moment to assume the natural leadership of his kinsmen and participated in social movement and got involved in founding the constitutional edifice of the country. $\mathrm{He}$ was one of the front-ranking nation-builders of modern India. He is popularly considered as the 'pioneer' who initiated the 'liberation movement' of roughly sixty-five million untouchables of India of his time. For, Ambedkar, notwithstanding his birth in a lower caste, the Mahar community of Maharashtra, has made an indelible imprint on the body politic of the country. As regards the emancipation of the backward classes, first he criticized the caste Hindus for their social apathy towards the depressed classes, blamed the British for their political and economic backwardness and stood as the unrivalled champion of the depressed classes, and dedicated his life to the cause of their amelioration. As a brilliant scholar on Indian Society and intellectual wellversed with writings of great scholars in east and west, Ambedkar all through his life reflected the problem of untouchables. A glance at his profuse writings would evidently show that despite his preoccupations with the problems of the dalits, Ambedkar had, in his own way, made significant contribution to the contemporary political ideas.

The present study is an attempt to make a brief objective analysis of the various strands of the political ideas of Ambedkar while keeping in minds the gaps and lapses in the existing literature on Ambedkar.

\section{Analysis of Various strands of Political thought of B.R.Ambedkar:}

I

Several factors that Ambedkar encountered with, contributed to the formation of his political ideas. In fact, the experiences he gathered during his life at different levels-personal, intellectual as well as socio-political -exerted deep influence on the formulation of his ideas. Encounter with English education in India and abroad helped Ambedkar to come into contact with several contemporary thinkers intellectuals. However, in some cases, the contact was not personal, but through their ideas, those thinkers had attracted Ambedkar intellectually. Ambedkar was greatly inspired by the ideas of Indian social reformers. He was greatly influenced by the philosophical ideas of Lord Buddha, Mahatma Jotiba Phule, Kabir and Dalit saints like Nandnar, Ravidas and Chokhamela. He dedicated his book, "The untouchables who were they and why they become untouchable?" to the memory of Nandanar, Ravidas and Chokhamela. The three renowned saints were born among the untouchables and by their piety and virtue won the esteem of all. Ambedkar admired those saints for their challenge to the orthodox Hindus and religious guidelines to the downtrodden. ${ }^{1}$ Ambedkar was a different reader and had been very good in Sanskrit, Persian, Marathi, Hindi and English. Through the books he read, he drew lot of inspiration. These books had great impact on Ambedkar's struggle for social justice.

Ambedkar's proficiency in Sanskrit made him to have wide knowledge about Hinduism. Ambedkar would recite Mahabharata, Ramayana, Upanishads, Manusmriti, and other religious texts. Due to his vast reading, he could assess the drawbacks of these texts and could build his own theories. His books on "Caste in India", "Annihilation of caste", "Philosophy of Hinduism", "Revolution and counter Revolution in Ancient India", Who were the Shudra" and "Riddles in Hinduism" which Ambedkar had derived from the original Hindu religious texts. Ambedkar had studied great deal of literature on religious, social, political and economic life of India. Hopkins's "The Great Epic of India", C. V. Vaidya's "The Riddle of the Ramayana" and "History, Manners and Customs" and Prof. D. S. Triveda's "The original home of the Aryans" were some of great books which 
Ambedkar read with great interest and delight which contributed in no mean way to the development of his own ideas. Further, Ambedkar had studied stand by Rice's Hindu customs and their origins. He read this book to know how untouchability had come into existence. ${ }^{3}$ Ambedkar saw much in common in Prof. Envile Durkheim's "The Elementary forms of the Religious life,"4 Goethe's "Marxisms and Reflections",5 and Gorky's literature and life. ${ }^{6}$ They gave imagination and intuition to Ambedkar to write on the origin of untouchablity.

Since Ambedkar has exposed to western countries, he was attracted by western liberal doctrines and tradition which he upheld in his approach to the study of socio-economic problems of India. Ambedkar thoroughly read books written by liberal writers like Walter Bagehot, James Bryce, Jennings, Pendleton Herring, Prof. A. B. Hart, Prof. L. T. Hobhouse, John Shore, Prof Dicey, Porritt, Prof. L. H. Laski and many others. Ambedkar's traces the failure of the liberal party in India by referring to Pendleton Herring's "Politics of Democracy" 7 .

Ambedkar's reading on constitution and constitutionalism was very extensive and the citations from the books of constitutional expert in the constituent Assemble are a clear evidence of his awareness of the writings of experts in the field. Ambedkar appreciated Dicey's "Law of the constitution" for its serious limitations on sovereignty. ${ }^{8}$

According to Bagehot, parliamentary government means government by discussion and not by fisticuffs. Ambedkar's had vast knowledge about parliamentary form of democracy. This was possible due to his extensive reading to the writings of experts of democracy. He said that to his knowledge, no one had explained the relationship of the king and his minister in a responsible government better than Macaulay. 9

Books were a constant company and Ambedkar managed to read books even when he was totally involved in public life. His very extensive reading helped him to speak and write with authority and confidence on the political, social, economic, religious problem of India. Tormentation of depressed classes by the upper class to which Ambedkar himself was a victim has made indelible impression on his intelligent mind.

Secondly, as a brilliant scholar on Indian Society and intellectual well-versed with writings of great scholars in east and west, Ambedkar all through his life reflected the problem of untouchables.

The analysis of influences of the philosophical ideas of Buddha, Kabir, Phule, Tukaram, Burke, Seligman, Dewey, Russell etc on Ambedkar unfolds the impact of various intellectual personalities on Ambedkar which might have led Ambedkar towards making a critical analysis on the concrete problems facing humanity. Undoubtedly, progressive thinking of those intellectual personalities had shaped his mindset.

The social aspects of Ambedkar's political ideas- issues of caste, politics of untouchability highlighting Gandhi and Ambedkar debate, his views on social justice made an indelible imprint on Indian society. Ambedkar was born in a society based on inequality. He was privileged enough to receive education in the west where he came under the influence of the liberal- minded professors like Dewey, Harold Laski, Seligman and others. It was, therefore, quite natural that he imbibed the spirit of liberty. This explains why he was against dictatorship, autocracy and totalitarianism. As a social philosopher, Ambedkar had developed logical structure of interrelated ideas which he used as a theoretical framework to explain the social phenomenon as well as to suggest changes in the existing pattern of social relations. Being an integral and organic part of that stratum of society which for generations together had been the victim of organized exploitative system, he had the advantage of having clear vision of the problems and complexities of the social system. Ambedkar tried to eliminate inequality and injustice and reformed the untouchables through the weapon of education. Ambedkar's birth in an untouchable community and in a system based on graded inequality and injustice and deprivation of basic human rights to his community was responsible for giving a purpose and a mission to his life. Unquestionably, he played a major role in quest for constitutional rights and social justice in the Constituent Assembly. Constitutional provisions aimed at preventing discrimination and promoting social justice are his major achievements. Ambedkar's philosophy of constitutionalism revolved around social justice and change through perfectly constitutional means. He dreamt of an equal society in India where there would be no discrimination, no exploitation, no untouchability and no degradation.

As an untouchables, Ambedkar was subjected to severe insults and indignities not only during his student days but also during the days he was occupying important positions in Government. The ghost of untouchability was closely haunting him wherever he went. That made him fight tooth and nail to remove its root and branch. It may be noted in this connection that the method resolving the issue of untouchability, adopted by Ambedkar was not the liking of Mahatma Gandhi who had also at the time fought against the problem in his own way.

Although Ambedkar and Gandhi began social and political activities for eradication of untouchability almost in same period, Ambedkar firmly believed in social movement rather than political movement. In the struggle for the freedom of the country, Gandhi, on the other hand, had the support of the millions of Indians, but in the struggle for liberation of the untouchables, many opposed him. Ambedkar was for the establishment of absolute equality in all spheres of national life. Gandhi claimed that he was the sole representative of the Hindus and as such he considered that untouchables were a part of Hindu community, he would not like anybody expect himself to represent the untouchables only. 
Gandhi also opposed Ambedkar's participation in the Round Table Conference (RTC) as a representative of the untouchables. Congress boycotted the RTC. But, Ambedkar made no secret about the controversy over the separate electorates arguing its advantages. The idea behind "Communal Award" scheme was to give proper representation to the depressed classes in the legislatures on the ground that it would be difficult for them to get elected in the general constituencies. Gandhi was afraid that if the British government would accept the scheme of separate electorates, the caste Hindus' relationship with the untouchables would come to an end, and the Hindu society would be divided.

\section{II}

Now, an attempt has been made to evaluate Ambedkar's self generated vision regarding nationalism with reference to the current debates relating to his role in freedom struggle, his idea of democracy, equality and freedom, political resistance and also his idea of socialism.

Ambedkar's nationalism started with a different cause which amounted to the welfare of the downtrodden and the poor. He had full faith in the greatness of his country and the dignity of his countrymen. Nationalism in him began as a protest, both against external domination and internal oppression. Ambedkar has expressed his feelings as regards nationalism, in terms of majority and minority. Ambedkar opposed the civil disobedience movement started by Gandhiji in 1930. He thought that it was extremely inopportune. He remarked that this movement was not a rebellion as it could not throw out the British bureaucracy. Similar reaction was expressed by him on the eve of the "Quit India" movement. The failure to situate Ambedkar in a proper historical and nationalist perspective has left the ground quite wide open for such critics, for example, Arun Shourie to launch hurtful attack on Ambedkar. Arun Shourie finds fault with Ambedkar for opposing the National Movement. It is true that Ambedkar never participated in the freedom struggle rather he opposed it. But, it is indeed a fact that his opposition helped to widen the internal scope of the freedom which made it really significant for thousands of oppressed people. Nationalism is not is a blind worship of the motherland. It is true that Ambedkar's opposed the mainstream national movement, but this kind of attitude indirectly contributed much by laying the broad social foundation on which the present Indian nation state stands. Without Ambedkar's intervention to bring about some measures of material empowerment of the former untouchables, they would have been unable to their rightful place in national life. The above mentioned interaction made it possible the proper understanding of the true significance of the scheduled caste problems. Ultimately, this influenced Gandhiji's unhesitant decision to accept the request of the scheduled caste members of the constituent assembly that Ambedkar should be included in India's first Government. It was Ambedkar's political challenge which compelled congress to appreciate the national significance of the problem of the scheduled castes and to adopt certain measures which significantly contributed towards broadening and strengthening the social base of Indian nationalism.

A detailed analysis of his life and mission reveals that Ambedkar held the basic and fundamental norm, to be equality- social, economic and political, from which he proceeded to lay down a collection of 'ought' propositions; in this hierarchy of 'ought', the initial fundamental 'ought' on which the validity of all the other ultimately rests, the fundamental norm seems to be the social equality, the justification for the rest of the legal reforms and changes he persistently fought for. It was a society full of social inequalities in which Ambedkar was born. The humiliation he experienced in such an in egalitarian society bore on imprint in all thought his life.

Analyzing the idea of democracy of Ambedkar in details, it can be found out that Ambedkar had unshakeable faith in democracy. In his conception of exploitation less society, democracy has an extra-ordinary role which he defined as 'one person, one vote'; and 'one vote, one value'. Democracy means empowerment of any person for participating in the process of decision-making relating to him, democracy means liberty, equality and fraternity - Ambedkar's definition of democracy had such a tone. Because he presided over making of the Constitution and is being projected as its chief architect, there is a misunderstanding that parliamentary democracy is what he wanted. But nothing could be farther from the truth than this. He himself spoke against parliamentary democracy. His conception of democracy appears to be purely people oriented. He showed that the bookish concepts of equality are detrimental to the disabled sections of society in the prevailing social setting and proposed a fundamental change in the concept of equality. It envisaged complete abolition of inequality. His principle of positive discrimination is based on this very concept of equality. But, the operational aspects of this concept involved the need for some kind of autonomous institution, which was met by 'State' and 'religion'. Ambedkar firmly believed that political democracy cannot succeed without social and economic democracy. In his concept of democracy, he opined that political democracy is not an end in itself, but the most powerful means to achieve the social and economic ideals in society. State socialism within the framework of parliamentary democracy can defeat dictatorship. Fundamental rights without economic security are of no use to the have-nots. He was against coercive centralized institutional authority that Hobbesian philosophy maintains. Associated life is consensual expression of shared experience, aspirations and values. Thus, Ambedkarism is of great bearing to Indian society even in the present day in achieving social justice, removal of untouchability, in establishing equality and freedom and true democracy. Democratic socialism is the key note of his political thought and 
constitutionalism is the only way to achieve it. In conclusion, it can be said that this research gives closer and analytical insight into the thoughts of Ambedkar and provides an answer to the question of whether we, the Indians, achieve religious tolerance, human equality and freedom, true democracy, gender respect in the society, justice and peace in the light of political philosophy of Ambedkar whose memory will ever guide the nation on the path of justice, liberty and equality.

Ambedkar's theory of political resistance reveals that his theory on political resistance was a deliberate mixture of social radicalism and political pragmatism which appropriately understood the pressure politics. In order to exercise pressure on the government with a very clear sighted use of political power, he influenced the depressed classes, to adopt two methods of Satyagraha (Non-violence) and agitation to resist the government. He approved both the methods but always pleaded for steering the middle course because he was of the perception that caste Hindu would not exhibit unilateral initiative to abolish untouchability without struggle. In the process of evolving a liberal democratic framework, in view of Ambedkar, pressure politics is more important than violent politics. Despite considering struggle as the heart of politics, he never completely follows 'Gandhi's theory of Satyagraha'. As far as moral basis of struggle is concerned, he agreed with Gandhi to that extent and stood for flexibility of means to be employed. Actually, Ambedkar believed that Swaraj alone would not bring democratic revolution in the country and it would rather be possible by means of putting the social order upside down.

\section{III}

Ambedkar's idea of socialism presents that although Ambedkar laid much emphasis on the economic dimension in socialism, he broadly remained a socialist. There is very little opportunity to suspect his socialist credentials because of his disapproval of Russell's criticism of property, his non-acceptance of Marxian formulations and his placement of social issues higher than the economic and political issues. But, in all evenhandedness, it may be said that what he appears to mean is the integrative consideration of all the factors that are needed for any society to be based on liberty, equality and fraternity. Notwithstanding his variant conception, there should not be any doubt about his socialistic background. His conception of socialism also underwent evolution. Once he had stated that there was hardly any difference between his socialism and communism. As such, his disagreement with the communists was about the means and not about the aim. He warns the communists that the classless society can emerge only after the emergence of a casteless society. Ambedkar rationally postulated that unless the consciousness of the working class was agreeable for revolution, there was no question of it materializing. And, unless the caste system is smashed, creation of the pro-revolution consciousness was out of question. It is unfortunate that the ideal of classlessness that was dormant in his agenda never really surfaced during his lifetime. It is also prevalent from the study that Ambedkar relies on the concept of 'State' for materialization of his conception of socialism. His conception of State is largely idealist. He wanted the State to intervene in the economic structure and its monitoring. He wanted to constitutionalize this State intervention so that it would not be subject to change any time with the whims of simple majority vote in the legislation. Ambedkar till the end could not completely remove the Fabian influence (which he might have gathered while in England) on him. The knowledge of Marxism seldom exceeded some broad principles and 'Stalin's dictatorship' painted by imperialists or the 'revolt of the workers, the insurgency of the poor. Ambedkar also does not seem to have gone very far from this point. Without indulging into the debate of ifs and buts, there should not be any bit of doubt that the ideal society of his conception could materialize only through socialism.

Jaffrelot remarks:

“....the outcome of Ambedkar's political career was definitely mixed. Undoubtedly he obtained major concessions from the British by collaborating with them-including a new policy of positive discrimination in favour of the untouchables- and his politics made an impact during the constitutional debates when he gained more concessions for the Dalits and succeeded in marginalizing some Gandhian propositions. But, he did not get the separate electorate he wanted for the Scheduled Castes, he failed to have concrete social reforms adopted, such as the Hindu Code Bill, he was not able to establish a party representing the interests of the Untouchables of India as a whole". ${ }^{10}$

As Ambedkar worked outside the mainstream of Congress politics and also criticized the Congress, he was suspected by many to be a separatist and pro-British. But all along, he remained a patriot. He used to say that patriotism was not the monopoly of Congress and that one could be patriotic without becoming a Congressman. He considered the uplift of the backward sections of the society to be more important than mere political emancipation of the country. Political freedom was meaningless without the elevation of the backward sections of the society. Mahatma Gandhi also held similar views as he thought of the concept of Swaraj in terms of the meanest of the countrymen.

Ambedkar's attitude towards imperialism has been projected in a distorted manner right from the beginning, mainly because he refused to take part in the freedom struggle or opposed Gandhi. In relation to British rule, 
Ambedkar questions the so-called freedom struggle launched under the leadership of Congress as an antiimperialist struggle. He contended that the Congress basically represented the class of feudal lords and the urban capitalists - the duo exploiters of Indian masses. Although, it succeeded through the charismatic leadership of Gandhi in galvanizing masses in its support, it essentially relied on bargaining with the colonial rulers for securing itself more share of power.

Shourie's allegation that Ambedkar did not participate in the freedom struggle of India would highlight the message that dalits in this country should now live under the obligation of Hindus who according to Shourie, achieved independence for this country. Shourie's argument also suggests that since Ambedkar and dalits did not participate in the freedom struggle, they are morally inferior to those who fought for India's freedom. According to this construction of nationalist struggle in India, Shourie appears to suggest that it is only the Hindus who can legitimately claim the tradition of freedom struggle and the dalits are the silent objects of the nationalist discourse in India. Second, of late, dalits in India are relating themselves to Ambedkar more intensively than ever before and this wider claim on Ambedkar as a cultural symbol is going to become an important rallying factor in the post- independence politics of consolidation of dalit- bahujan power particularly against the Hindutva forces representing Brahman-Bania nexus with the global capital. These forces which form the core of the Hindutva have now realized that their 'soft Hindutva' is no more effective in attracting the dalits to their fold. However, Shourie's book unfortunately does not cover the various aspects of Ambedkar's political thinking while offering his comments. ${ }^{11}$

Truly, the negative issue that is quite evident in his political thinking is that Ambedkar did not actively participate in nationalist/freedom movement of India nor his followers (Mahars) indulged in the movement .It might so happen that Ambedkar wanted internal consolidation of caste and society rather than political freedom. But, this indifferent attitude of Ambedkar in the Congress led freedom movement of India instigated critics to make harsh comment regarding his position as true nationalists. Moreover, being a representative of depressed classes, Ambedkar throughout his life exclusively fought for removal of untouchability, social equality and caste based reforms. Social emancipation of dalit rather than their political liberation was the priority in his revolutionary agenda.

The roots of his philosophy were not in politics but in religion. He regarded that the caste system must be annihilated because it was inhuman and detrimental to the upward march of the untouchables. According to Valerian Rodrigues, to incorporate values conducive to Democracy, Ambedkar put forth several strategies. Negatively, he identified Brahmanism as upholding values to democracy, he fostered agitation against it and suggested alternative ways of looking at traditions; he identified Buddhism as conducive to a democratic way of life; he challenged modern forms of authoritarianism, including Gandhi, and felt that they basically reinforced values and attitudes not conducive to a democratic temper. Positively, Ambedkar suggested the constitution of political power based on popular sanction with one man as one value, accountability of power under the rule of law, majoritarianism with appropriate protection to minorities, education and organisation of people for forceful but non-violent struggle and developing values and attitudes in families and institutions conducive to democracy. In fact, socialism might strengthen the existing authoritarian foundations in society. Therefore, while he wanted democracy to work towards socialism, he always wanted to have its basis in a regime of rights. ${ }^{12}$

Ambedkar was one of the pioneers of social justice in India. It was Ambedkar who provided new dimensions to the concept of justice. We regard him as the 'Champion of Social justice.' He was himself a victim of social injustice, faced its difficulties; and he not tolerated the injustice, but boldly fought against them. Ambedkar had a liberal concept of justice. Like Gandhi, for Ambedkar, justice is simply another name of liberty, equality and fraternity.' In this sense, the core value of Ambedkar concept of justice is human equality, equal distribution of the welfare materials and discrimination less society. Thus, the spirit of social justice, according to Ambedkar, gives a significant place to mutual sympathy and respect. ${ }^{13}$

Jaffrelot remarks:

"If the final outcome of Ambedkar's actions was rather mixed, the significance of his achievement must be seen within the wider scope of the pioneering objective that he had set himself. However, he would have had a bigger impact had he devoted more time to the organizational structures of the movements and parties which he engendered. Ambedkar's strengths were those of his weakness: nothing he achieved would have been possible without his strength of character which was so manifest and explains his tremendous charisma."14

\section{Conclusion}

Whatever he achieved, that would have been possible for his strength of character which manifested his individual charisma. As a statesman, scholar, crusader of downtrodden and above all a spiritual guide, Ambedkar has left an indelible impression on the Indian History. His contribution to uplift the downtrodden made him a cult figure among the depressed classes. He now lives in the heart and mind of the million of the suffering people. They now look at him as immortal soul whose memory will even guide the nation on the path of social 
justice, liberty and equality. Thus, Ambedkarism is of great relevance to Indian society even today in achieving social justice, removal of untouchability, in establishing equality and freedom and true democracy. Democratic socialism is the key note of his political thought and constitutionalism is the only way to achieve it.

In conclusion, it can be emphatically remarked that this article gives closer and analytical insight into the political thoughts of Ambedkar and provides an answer to the question of whether we achieve religious tolerance, human equality and freedom, true democracy in the society, justice and peace in the light of political philosophy of Ambedkar whose memory will ever guide the nation on the path of justice, liberty and equality. This article, therefore, besides reflecting the theoretical issues that are implicated in the writings of Ambedkar, also attempts to capture the position of Ambedkar on issues whose relevance is actually felt even in the present day. The complex issues which Ambedkar explained and defended, although not always to the satisfaction of many and sometimes not as rigorously as required, have continued to claim intellectual and political attention to this day in many societies and specially in India.

\section{Reference}

1. Ibid., p.4.

2. BAWS, op.cit., vol-9, p. 267.

3. Ibid., p. 271.

4.BAWS,The Untouchables Who were They and Why They became Untouchables, Op.cit.,vol-7, p. 351.

5. Ibid., p.242.

6.Ibid., p. 244.

7. BAWS, Ranade, Gandhi and Jinnah, op.cit, vol-1, p. 238.

8.Ibid., p.334.

9. Ibid., p.324.

10. Christtophe Jaffrelot, Analysing and Fighting Caste:Dr. Ambedkar and Untouchability,p.162.

11. Arun Shourie, Worshipping False Gods: Ambedkar and the Facts which have been erased, p.225.

12. Quoted in Sukhadeo Thorat Aryama(ed), Ambedkar in retrospect: Essays on Economics, Politics\& Society, p.153.

13. Vidhu Verma, Colonialism and Liberation: Ambedkar's Quest for Distributive Justice, Economic and Political Weekly, Sept.25, 1999, pp.2804-10.

14. Christtophe Jaffrelot, op.cit., p. 163.

\section{Select Bibliography:}

1.Dr Babasaheb Ambedkar: Writing and Speeches (vol.1-12), Education Department, Government of Maharashtra, Bombay.

2.Caste in India, Annihilation of caste, Thoughts on Linguistic states, Ranade, Gandhi and Jinnah, Federation versus Freedom, states and minorities, Mr. Russell and the Reconstruction of society, have been reproduced in BRAWS, vol-1.

3.Writings dealing on the Castes System and Its Implications, Revolution and Counter Revolution are included in BRAWS, vol-3.

4.Riddles on Hinduism in BRAWS, vol-4.

5. Who were the Shudras? And the Untouchables in BRAWS vol-7

6. What Congress and Gandhi have done to the Untouchables in BRAWS vol-9.

7.Pakistan or Partition of India, cautions on Nationalism in BRAWS vol-8.

8. Submissions before the Cripps Mission and the Cabinet Mission in BRAWS vol-10.

9.Essay on Untouchability and Writings included under Book IV in BRAWS, vol-5.

10.The "Grievance of the Scheduled castes", submitted to the Governor General in BRAWS vol-10.

The Constituent Assembly Debate.vol-9 1949.

[Acknowledgement: The author is thankful to his respected teacher, Dr Sarbapriya Ray, Associate Professor, Vivekananda College, under University of Calcutta, Kolkata and Guest faculty in the Dept of Commerce, University of Calcutta, Kolkata, India for reviewing the earlier draft of the article]. 